$\begin{array}{ll} & \text { Etnográfica } \\ \text { etnográfica } & \text { Revista do Centro em Rede de Investigação em }\end{array}$

Antropologia

vol. 17 (1) | 2013

Vol. $17(1)$

\title{
Charles Piot, Nostalgia for the Future: West Africa after the Cold War
}

\section{Pedro Pestana Soares}

\section{(2) OpenEdition \\ Journals}

Edição electrónica

URL: https://journals.openedition.org/etnografica/2633

DOI: 10.4000/etnografica.2633

ISSN: 2182-2891

\section{Editora}

Centro em Rede de Investigação em Antropologia

\section{Edição impressa}

Data de publição: 1 fevereiro 2013

Paginação: 209-211

ISSN: 0873-6561

\section{Refêrencia eletrónica}

Pedro Pestana Soares, «Charles Piot, Nostalgia for the Future: West Africa after the Cold War»,

Etnográfica [Online], vol. 17 (1) | 2013, posto online no dia 13 março 2013, consultado o 11 fevereiro 2022. URL: http://journals.openedition.org/etnografica/2633 ; DOl: https://doi.org/10.4000/ etnografica. 2633

Etnográfica is licensed under a Creative Commons Attribution-NonCommercial 4.0 International License. 
Charles Piot

NOSTALGIA FOR THE FUTURE: WEST AFRICA AFTER THE COLD WAR Chicago e Londres, The University of Chicago Press, 2010, 200 páginas, ISBN: 9780226669649.

Decorreram onze anos desde que Charles Piot publicou Remotely Global: Village Modernity in West Africa, obra em que propôs um reenquadramento da supostamente "remota" ruralidade africana, sublinhando a sua fluidez e abertura ao exterior e pondo em evidência a plasticidade com que cria as suas próprias regras e instrumentos para interagir com um mundo global e reclamar nele o seu lugar. Mas uma década apenas parece ter sido suficiente para, em Nostalgia for the Future, o Togo - e a África Ocidental - surgirem de tal forma transfigurados que, para o autor, os instrumentos e paradigmas teóricos da antropologia pós-colonial se arriscam a tornar-se obsoletos.

Um dos fatores que contribui para a marcada diferença nestes dois retratos do Togo começa por ser a sua abrangência geográfica. Se Remotely Global era um trabalho centrado na cultura kabre do Norte rural do país, Nostalgia for the Future abre os seus horizontes também aos espaços urbanos do
Sul, não apenas pela necessidade de compreender o campo em relação com a cidade, algo que se tornou incontornável com a crescente mobilidade e interdependência entre ambos, mas também por as cidades se terem constituído como portas de entrada de alguns dos grandes agentes de transformação das últimas décadas. E é nestas transformações, nas "novas soberanias, formas emergentes de poder, resistências difusas e ainda incoerentes, imaginários religiosos e recusa da tradição e da cultura híbrida" (pág. 8; tradução minha), que a África Ocidental surge agora como um terreno novo e, de certa forma, inesperado, quase irreconhecível em certos contextos, para o antropólogo.

Face às insuficiências que identifica nos estudos africanos e na antropologia pós-colonial, Piot apela às contribuições de outras áreas do saber e encontra no trabalho de Michael Hardt e Antonio Negri, Empire (2000), um modelo útil para sistematizar as transformações das últimas décadas incluindo no que concerne à transição das soberanias rígidas e verticais das épocas colonial e pós-colonial para as relações de poder horizontais, mais flexíveis e difusas, da contemporaneidade. Mas, ainda que o "Império" de Hardt e Negri nos possa ajudar a teorizar sobre este novo território, 
quais são os conteúdos e especificidades culturais que acompanham estas mudanças no Togo e na África Ocidental, ou seja, de que forma responderam os togoleses ao final da Guerra Fria e à profunda crise que o acompanhou?

Para responder a esta questão, o autor começa por explorar as consequências imediatas da retirada dos interesses internacionais da África Ocidental durante os anos 1990. A transformação do Estado patrimonial num "regime de simulacro", subsistindo graças ao espetáculo e à "dramaturgia”, teve como efeito mais imediato o abandono das responsabilidades estatais nos campos social e de desenvolvimento, o que, sublinha o autor, conduziu a uma das mais dramáticas transformações na história recente de África: o fim do sistema de indirect rule nas zonas rurais, iniciado durante a época colonial e perpetuado sensivelmente nos mesmos moldes durante o período pós-colonial e até ao final da Guerra Fria. Consequentemente, as chefias e gerontocracias que há muito governavam as aldeias entraram em declínio, o vasto aparato cerimonial que concedia autoridade aos chefes e anciãos passou a ser rejeitado e a "democracia" e os "direitos do homem" entraram no discurso quotidiano da generalidade dos togoleses.

O recuo do Estado e das estruturas de poder pós-coloniais na África Ocidental criou assim vastas zonas "cinzentas" - para Piot, todo o território togolês é uma zona de progressivo "acinzentamento" - de soberanias instáveis e incertas, onde novos agentes criam relações de poder erráticas e, em larga medida, imprevisíveis. Contudo, enquanto Hardt e Negri parecem descartar o papel da religião na conjuntura global pós-Guerra Fria, Piot acredita que essas transformações não só influem de forma determinante na reconfiguração do panorama religioso, como são, em grande medida, movidas por ele. Ainda que dedique todo um capítulo à atuação das ONG como substituto precário da função social e de desenvolvimento que o Estado desempenhava nessas zonas agora "cinzentas", a importância nuclear que dá às igrejas carismáticas neopentecostais é claramente superior. Para ele, é na muito acelerada expansão destas igrejas ao longo das últimas duas décadas que se refletem de forma mais exemplar as dinâmicas entre tradição e modernidade, entre ruralidade e urbanidade, que subjazem à "morte de uma cultura" - título do último capítulo do livro e prenunciam uma nova era de contornos ainda indefinidos.

O conflito entre as igrejas neopentecostais e as religiões locais, alimentado por acusações mútuas de feitiçaria, irradiando das cidades para o interior rural que é último reduto da "tradição", surge como consequência, mas também como motor, de uma cultura em crise e em modo de pânico. Da mesma forma, a recusa dos neopentecostais em aceitar formas religiosas híbridas e sincretismos tipicamente pós-coloniais indica uma opção intencional pelo choque e pela rutura. Para Piot, os imaginários religiosos não são um mero reflexo ou resposta a uma crise externa, eles são essa crise, "não tanto no sentido de a terem inventado mas antes de se terem apropriado dela, de a terem amplificado e moldado a seu bel-prazer" (págs. 129-130; tradução minha).

É esta ênfase na agência das populações abandonadas - pelo seu governo, pela sua cultura, pelas potências internacionais e as ONG - que leva o autor a distanciar-se de Jean e John Comaroff, os quais, segundo Piot, atribuem um papel demasiado passivo às "vítimas" do neoliberalismo que varreu o continente africano e da consequente crise de reprodução dos processos sociais. Piot considera que os togoleses estão plenamente conscientes da sua posição no mundo contemporâneo, da sua exclusão da modernidade europeia, e que o desejo de participar nela se traduz numa pletora de 
novas estratégias que abrem novas possibilidades entre as ruínas de antigas estruturas de poder que forçavam a sua submissão.

Como qualquer obra que se assume "de charneira", que marca um ponto de rutura num momento em que o futuro é ainda indefinido e o presente é difuso, maleável e ambíguo, Nostalgia for the Future corre alguns riscos, principalmente ao propor um alargamento da análise da situação togolesa a toda a África Ocidental, e ao assentar num trabalho de campo que nas cidades é metodologicamente menos consistente do que no interior rural - algo compreensível, tendo em conta que, até recentemente, o trabalho etnográfico do autor no Togo se centrou no mundo rural.

Apesar das suas potenciais lacunas, esta obra de Piot surge como de leitura essencial ao construir-se, acima de tudo, em torno do desafio e da urgência. Em primeiro lugar para um continente, ou parte dele, que se debate por responder a transformações dramáticas nas estruturas e processos sociais que o regiam há pelo menos um século. Mas também para o africanista e o antropólogo, ao desafiá-lo a "ver a 'cultura' e a 'tradição' como atávicas e o pentecostalismo como progressivo, a avaliar a 'agência' através da adoção, e não da rejeição, da euroalteridade, a procurar a política em lugares insuspeitos e a abdicar das noções familiares que dela conservamos" (pág. 10; tradução minha). Despojado das culturas "autóctones" albergadas sob o aparato colonial da primeira metade do século XX, mas também dos hibridismos celebrados pela reencarnação da antropologia enquanto estudos pós-coloniais, o antropólogo, diz-nos Piot, tem agora de se comprometer com uma posição em que, para encontrar um caminho viável para o futuro, terá de sacrificar muito do que, no passado, lhe serviu de orientação.

\section{Pedro Pestana Soares}

Instituto de Ciências Sociais da Universidade de Lisboa, Portugal pestanasoares@gmail.com 